\title{
Plant structure predicts leaf litter capture in the tropical montane bromeliad Tillandsia turneri
}

\author{
F. Ospina-Bautista ${ }^{a, b *}$ and J. V. Estévez Varón ${ }^{b}$ \\ aLaboratorio de Zoología y Ecología Acuática, Departamento de Ciencias Biológicas, Universidad de Los Andes, \\ Carrera 1 No. 18A-12, Apartado 4976, Bogotá D.C., Colombia \\ ${ }^{\mathrm{b}}$ Grupo de Investigación en Ecosistemas Tropicales, Departamento de Ciencias Biológicas, Universidad de Caldas, \\ Calle 65 No. 26 -10, Manizales, Caldas, Colombia \\ *e-mail: fospinab@hotmail.com; mf.ospina35@uniandes.edu.co
}

Received: December 12, 2014 - Accepted: June 17, 2015 - Distributed: August 31, 2016

(With 1 figure)

\begin{abstract}
Leaves intercepted by bromeliads become an important energy and matter resource for invertebrate communities, bacteria, fungi, and the plant itself. The relationship between bromeliad structure, defined as its size and complexity, and accumulated leaf litter was studied in 55 bromeliads of Tillandsia turneri through multiple regression and the Akaike information criterion. Leaf litter accumulation in bromeliads was best explained by size and complexity variables such as plant cover, sheath length, and leaf number. In conclusion, plant structure determines the amount of litter that enters bromeliads, and changes in its structure could affect important processes within ecosystem functioning or species richness.
\end{abstract}

Keywords: leaf litter, Bromeliaceae, plant structure, tropical montane forest.

\section{A estrutura da planta determina a folhagem interceptada pela bromelia Tillandsiaturneri}

\begin{abstract}
Resumo
As folhagens interceptadas pelas bromélias é um importante recurso para a comunidade de invertebrados, bactérias, fungos e para a própria planta. Estudou-se a relação entre a estrutura de 55 bromélias de Tillandsia tumeri, definida como o tamanho, a complexidade da planta, a folhagem acumulada por meio de regressão múltipla e o critério de informação de Akaike. Encontrou-se que as variáveis de tamanho, cobertura, comprimento da bainha e a variável de complexidade do número de folhas explicam a acumulação de folhas nas bromélias. Em conclusão, a estrutura do planta determina a quantidade de folhas armazenada na bromélia e os câmbios da estrutura da bromélia poderiam afetar importantes processos de funcionamento do ecossistema ou a riqueza de espécies.
\end{abstract}

Palavras-chave: folhagens, Bromeliaceae, estrutura do planta, floresta tropical montana.

\section{Introduction}

Leaf litter is the most significant energy and matter resource for detrital food webs (Anderson and Sedell, 1979; Hattenschwiler et al., 2005) as litter decomposition directs nutrient cycling through the conversion of organic material to its mineral form (Swift et al., 1979). Although most leaf litter in a forest falls directly to the soil, a part of it is intercepted by tree canopies, shrubs (Lodge, 1996), understory plants (Alvarez-Sanchez and Guevara, 1999), and vascular epiphytes such as bromeliads (Lodge, 1996).

Leaves intercepted by bromeliads become an important energy and matter resource for invertebrate communities (Maloney and Lamberti, 1995; Yanoviak, 1999) and the plant itself (Ngai and Srivastava, 2006). Leaf litter intercepted by bromeliads provides microhabitat and nutrients to organisms such as bacteria and fungi, detritivores, and deposit feeders (Frank, 1983; Armbruster et al., 2002). As a consequence, leaf litter affects the organisms associated with this micro-ecosystem, for example, invertebrate richness and abundance are related to the amount of litter in Guzmania spp. Ruíz and Pav. 1802 and Vriesia spp. Lindl. 1843 (Richardson et al., 2000), and the proportion of hunting spiders increases with greater litter depth in individuals of Aechmea distichantha Lem. 1853 (Montero et al., 2010). Additionally, bromeliads obtain nutrients from litter intercepted by rosettes, which are absorbed through specialized trichomes (Benzing and Renfrow, 1974; Benzing, 2000) and are important for 
reproduction, fitness, and growth (Benzing, 1990; Lasso and Ackerman, 2013).

Although leaf litter is relevant to associated organisms and the plant itself, little attention has been given to factors, such as bromeliad structure, that could determine the amount of leaf litter retained by the plant as well as its effect on the invertebrate community. Moreover, bromeliad structure has only been related to the invertebrate community associated with bromeliads (Richardson, 1999; Armbruster et al., 2002; Araújo et al., 2007), vertebrate species (Cruz-Ruiz et al., 2012), the amount of water (Zotz and Vera, 1999), prey vulnerability (Saha et al., 2009), and detrital processing (Srivastava, 2006). In this study, we evaluated the relationship between bromeliad structure and the amount of litter retained, and built a model to predict leaf litter capture using measures of plant structure in Tillandsia turneri Baker 1888.

\section{Material and Methods}

The study was conducted in a tropical montane forest (Holdridge, 1967) at $3000 \mathrm{~m}$ and $3100 \mathrm{~m}$ of elevation. This forest is a 70 years old mature forest located in El Santuario ranch (Cundinamarca, Colombia), near El Sisga dam $\left(5^{\circ} 01^{\prime} \mathrm{N}, 73^{\circ} 42^{\prime} \mathrm{W}\right)$. The mean annual rainfall is $924.7 \mathrm{~mm}$. The precipitation regimen is unimodal with the dry season from September to April; the mean annual temperature is $11.9^{\circ} \mathrm{C}$ and the annual sunshine is 1264.1 hours. Average canopy height is $18 \mathrm{~m}$, with some trees growing up to $30 \mathrm{~m}$; the basal area is $51.35 \mathrm{~m}^{2} / \mathrm{ha}$ and the number of plant individuals per hectare is 3510 . The most common of 27 tree species at the site were: Weinmannia tomentosa L f. 1781, Drymis granadensis Lf., and Myrsine ferruginea (Ruíz and Pav. 1802) Spreng 1825. The bromeliads in this forest included T. turneri Baker 1888, Guzmania gloriosa (Andre') Andre' ex Mez. 1897, Racinaea tetrantha (Ruíz and Pav.1802) M.A. Spencer and L.B. Sm., T. biflora Ruíz and Pav.1802, T. complanata Benth 1846, and T. fendleri Griseb. 1865. Litterfall is $5264.31 \mathrm{~kg} / \mathrm{ha}$ in a year and is unrelated to the monthly precipitation, air temperature, and evaporation (Estevez Varón and Viña, 1999).

Tillandsia turneri is the most abundant tank bromeliad in this ecosystem (Isaza et al., 2004); the fauna associated with T. turneri is well known (Ospina et al., 2004, 2008). In order to estimate leaf litter weight inside 53 adult T. turneri individuals in the forest, bromeliads were collected from January to May of 2000. For this study, leaf litter only included leaves from the canopy. The samples were packed in labeled bags and then taken to the laboratory where they were dried at $80^{\circ} \mathrm{C}$ for 72 hours. The dry mass of the fallen leaves was determined using an analytical scale to the nearest $0.01 \mathrm{~g}$.

Bromeliad structure is defined by its size and complexity. Bromeliad size was measured through plant height (determined as the vertical distance between the plant base and the tip of the highest leaf), plant cover, which was calculated as the area of a circle with the same diameter as the plant diameter (plant diameter measured as the average between the distance between the most external leaves of the bromeliad and the diameter perpendicular to this first axis) (Richardson, 1999), leaf length and width, and sheath length and width of the four longest leaves of each plant. Complexity was measured through leaf number.

We performed regression models with bromeliad variables in order to investigate the relationship between litter amount on the phytotelmata and bromeliad size and complexity. The litter amount was transformed as $\mathrm{y}^{\wedge} 0.5$ and the assumptions of normality, collinearity, linearity and homoscedasticity were tested. We did not consider interaction terms among variables. We calculated the AICc (Akaike information criterion corrected) value through the formula: $\mathrm{AICc}=\mathrm{nLog}(\mathrm{RSS} / \mathrm{n})^{2}+2 \mathrm{~K}(\mathrm{n} /(\mathrm{n}-\mathrm{K}-1))$; where $\mathrm{n}$ is the number of observations, RSS is the residual sums of squares, and $\mathrm{K}$ is the number of parameters (Anderson, 2008). The best model was determined by examining the differences relative to smallest $\mathrm{AIC}, \Delta \mathrm{i}=\mathrm{AICi}-\min \mathrm{AIC}$; where $\Delta$ iis the difference between the AIC of the best fitting model and that of model $i$, AICiis the AIC for the model $\mathrm{i}$, and min AIC is the minimum AIC value of all models.

Model probability was found with the formula: $w_{\mathrm{i}}=\exp$ $\left(-0.5^{*} \Delta_{\mathrm{i}}\right) / \sum_{\mathrm{r}=1}^{\mathrm{R}} \exp \left(-0.5^{*} \Delta_{\mathrm{r}}\right)$; where wiis the Akaike weightfor model $\mathrm{i}$, the numerator is the relative likelihood, given the data, for model $\mathrm{i}$, and the denominator is the sum of the relative likelihoods for all candidate models. Furthermore, we found the evidence of each model with the formula: $\mathrm{E}_{\text {min } \mathrm{r}_{\mathrm{i}}}=\mathrm{w}_{\min } / \mathrm{w}_{\mathrm{i}}$.

We calculated the composite or averaged model with its unconditional standard errors (SE) through the formula: $S E=\left(\left(\mathrm{se}^{2}+\mathrm{MSV}\right) * \mathrm{w}\right)^{1 / 2}$ where MSV is calculated as (model average estimate - raw parameter estimate) ${ }^{2}$ and $\left(\mathrm{se}^{2}\right)$ is the square of the standard error of regression. The SE values allow us to determine the precision of the estimated model and variables; therefore, if the SE value is two times greater than the estimated parameter, then we can conclude that this parameter is not a good estimator of the response variable (Anderson, 2008). In order to evaluate the relative importance of each variable, we established the weight of each explanatory variable using the function to calculate relative importance metrics for linear models (calc.relimp) with $\mathrm{R}^{\wedge} 2$ contribution averaged over orderings among regressors (Chevan and Sutherland, 1991). The statistical analyses were done using the $R$ statistic program (R Development Core Team R, 2013).

\section{Results}

The $T$. turneri individuals selected in the study presented high variability in the structure variables, for instance, plant cover varied from 483 to $6249 \mathrm{~cm}^{2}$ and leaf number from 32 to 93 (see Table 1). Moreover, the T. turneri individuals contained $38.54 \mathrm{~g}+/-20.36$ of litter.

The model with the lowest AICc and the highest $\mathrm{m}$

odel probability included plant cover, leaf number, and sheath length variables was the best model to explain the variation in leaf litter amount present in the bromeliads (Table 2). The model was statistically significant and 
Table 1. Mean, Standard error, Minimal and Maximal of structure variables of Tillandsia turneri.

\begin{tabular}{lcccc}
\hline \multicolumn{1}{c}{ Variable } & Mean & Sd & Minimal & Maximal \\
\hline Coverage $\left(\mathrm{cm}^{2}\right)$ & 3114 & 1160.59 & 483 & 6249 \\
Height $(\mathrm{cm})$ & 45.14 & 9.66 & 25.00 & 70.50 \\
Number of leaves & 54.79 & 13.09 & 32.00 & 93.00 \\
Leaf length $(\mathrm{cm})$ & 42.05 & 7.4228 & 25.06 & 66.05 \\
Leaf width $(\mathrm{cm})$ & 4.275 & 0.8056 & 2.600 & 6.120 \\
Sheath length $(\mathrm{cm})$ & 17.66 & 2.3716 & 12.88 & 24.60 \\
Sheath width $(\mathrm{cm})$ & 7.229 & 1.1557 & 4.550 & 9.900 \\
\hline
\end{tabular}

Table 2. Model tested to evaluate the effect of bromeliad structure parameters on leaf litter amount.

\begin{tabular}{|c|c|c|c|c|c|c|}
\hline Model & RSS & AICc & $\Delta \mathrm{AIC}$ & $\begin{array}{c}\exp \\
(-0.5 * \Delta)\end{array}$ & $\omega$ & $\mathbf{E}$ \\
\hline L.N $+\mathrm{C}+\mathrm{S} . \mathrm{L}$ & 89.868 & 188.39 & 0 & 1 & 0.1165 & 1 \\
\hline L.N + P.H + C & 90.545 & 188.79 & 0.4 & 0.81 & 0.0954 & 1.2214 \\
\hline L.N + C & 94.431 & 189.02 & 0.63 & 0.7297 & 0.0851 & 1.3702 \\
\hline $\mathrm{L} . \mathrm{N}+\mathrm{P} . \mathrm{H}+\mathrm{C}+\mathrm{S} . \mathrm{L}$ & 88.029 & 189.3 & 0.91 & 0.6344 & 0.0739 & 1.5761 \\
\hline L.N + P.H + C + L.L + S.L & 85.64 & 189.3 & 0.91 & 0.6344 & 0.0739 & 1.5761 \\
\hline L.N + C + L.L + S.L & 89.057 & 189.84 & 1.45 & 0.4843 & 0.0564 & 2.0647 \\
\hline L.N + C + S.L + L.W & 89.387 & 189.91 & 1.52 & 0.4676 & 0.0545 & 2.1382 \\
\hline L.N + C + S.L + S.W & 89.8 & 190.11 & 1.72 & 0.4231 & 0.0493 & 2.3631 \\
\hline L.N + P.H + C + L.L & 89.971 & 190.35 & 1.96 & 0.3753 & 0.0437 & 2.6644 \\
\hline L.N + P.H + S.L & 93.631 & 190.46 & 2.07 & 0.3552 & 0.0414 & 2.8151 \\
\hline L.N + P.H + C + L.W + S.L & 87.317 & 190.57 & 2.18 & 0.3362 & 0.0392 & 2.9742 \\
\hline L.N + P.H + C + L.L+ L.W & 87.949 & 190.87 & 2.48 & 0.2893 & 0.0337 & 3.4556 \\
\hline L.N + P.H + C + S.L + S.W & 87.968 & 191.25 & 2.86 & 0.2393 & 0.0279 & 4.1786 \\
\hline L.N + P.H + C + L.L + L.W + S.L & 84.759 & 191.26 & 2.87 & 0.2381 & 0.0277 & 4.1996 \\
\hline L.N + C + L.L + L.W + S.L & 88.558 & 191.29 & 2.9 & 0.2345 & 0.0273 & 4.2631 \\
\hline L.N + P.H + C + L.L + S.L + S.W & 85.601 & 191.62 & 3.23 & 0.1988 & 0.0231 & 5.0278 \\
\hline L.N + P.H + C + L.W + S.L + S.W & 85.616 & 191.82 & 3.43 & 0.1799 & 0.0209 & 5.5566 \\
\hline L.N + P.H + L.L + S.L & 92.765 & 192.08 & 3.69 & 0.1580 & 0.0184 & 6.3281 \\
\hline $\mathrm{C}+\mathrm{S} . \mathrm{L}$ & 100.753 & 192.45 & 4.06 & 0.1313 & 0.0153 & 7.6140 \\
\hline L.N + P.H + C + L.L + L.W + S.L + S.W & 84.139 & 192.9 & 4.51 & 0.1048 & 0.0122 & 9.5352 \\
\hline P.H $+\mathrm{C}+$ S.L & 97.989 & 192.98 & 4.59 & 0.1007 & 0.0117 & 9.9244 \\
\hline L.N + P.H + C + L.L+ L.W + S.W & 87.673 & 193.08 & 4.69 & 0.0958 & 0.0111 & 10.4332 \\
\hline L.N + C + L.L + L.W + S.L + S.W & 87.79 & 193.15 & 4.76 & 0.0925 & 0.0107 & 10.8049 \\
\hline L.N + P.H + L.L+ L.W + S.L & 91.479 & 193.34 & 4.95 & 0.0841 & 0.0098 & 11.8817 \\
\hline P.H + C + L.L + S.L & 96.679 & 194.27 & 5.88 & 0.0528 & 0.0061 & 18.9158 \\
\hline L.N + P.H + L.L + L.W + S.L + S.W & 90.442 & 194.73 & 6.34 & 0.0420 & 0.0048 & 23.8074 \\
\hline $\mathrm{P} . \mathrm{H}+\mathrm{C}+\mathrm{L} . \mathrm{L}+\mathrm{L} . \mathrm{W}+\mathrm{S} . \mathrm{L}$ & 94.765 & 195.21 & 6.82 & 0.0330 & 0.0038 & 30.2652 \\
\hline L.N + S.L & 106.61 & 195.45 & 7.06 & 0.0293 & 0.0034 & 34.1239 \\
\hline P.H + C + L.L + L.W + S.L + S.W & 94.762 & 197.21 & 8.82 & 0.0121 & 0.0014 & 82.2694 \\
\hline
\end{tabular}

$\mathrm{RSS}=$ residual sums of squares; $\mathrm{AICc}=$ Akaike's information criterion; $\triangle \mathrm{AIC}=$ delta of $\mathrm{AIC} ; \mathrm{w}=\mathrm{AIC}$ weight; $\mathrm{E}=\mathrm{evidence}$. L.N= leaf number; $C=$ Coverage; $S . L=$ Sheath length; P.H=Plant height; $S . W=$ Sheath width; $L . W=$ Leaf width; L.L= Leaf length.

explained $29.82 \%$ of variation in leaf litter amount present in the bromeliads $\left(\mathrm{F}_{3,49}=8.36, \mathrm{p}=0.0001, \mathrm{R}^{2}=0.30\right.$; litter $=0.37+0.0005$ plant cover +0.035 leaf number +0.12 sheath length). In this model, plant cover and leaf number were the variables that most contributed to explaining litter weight in bromeliads (plant cover: $\mathrm{t}=3.02, \mathrm{df}=49$, $\mathrm{p}=0.004$, leaf number: $\mathrm{t}=2.44, \mathrm{df}=49, \mathrm{p}=0.018$ ) (see Figure 1). Moreover, this model is 1.22 times more likely to be the best explanation for litter amount compared to the second model, which included plant cover, leaf number, and plant height variables (see Table 2). According to the evidence, the most probable models are those that include plant cover, leaf number, and sheath length combined with plant height, because their evidence values are less than four (Anderson 2008). The weight of each variable was: sheath length 0.16 , plant cover 0.52 , and leaf number 0.32 ; therefore, leaf number and plant cover are highly plausible explanations for leaf litter amount, but, given 

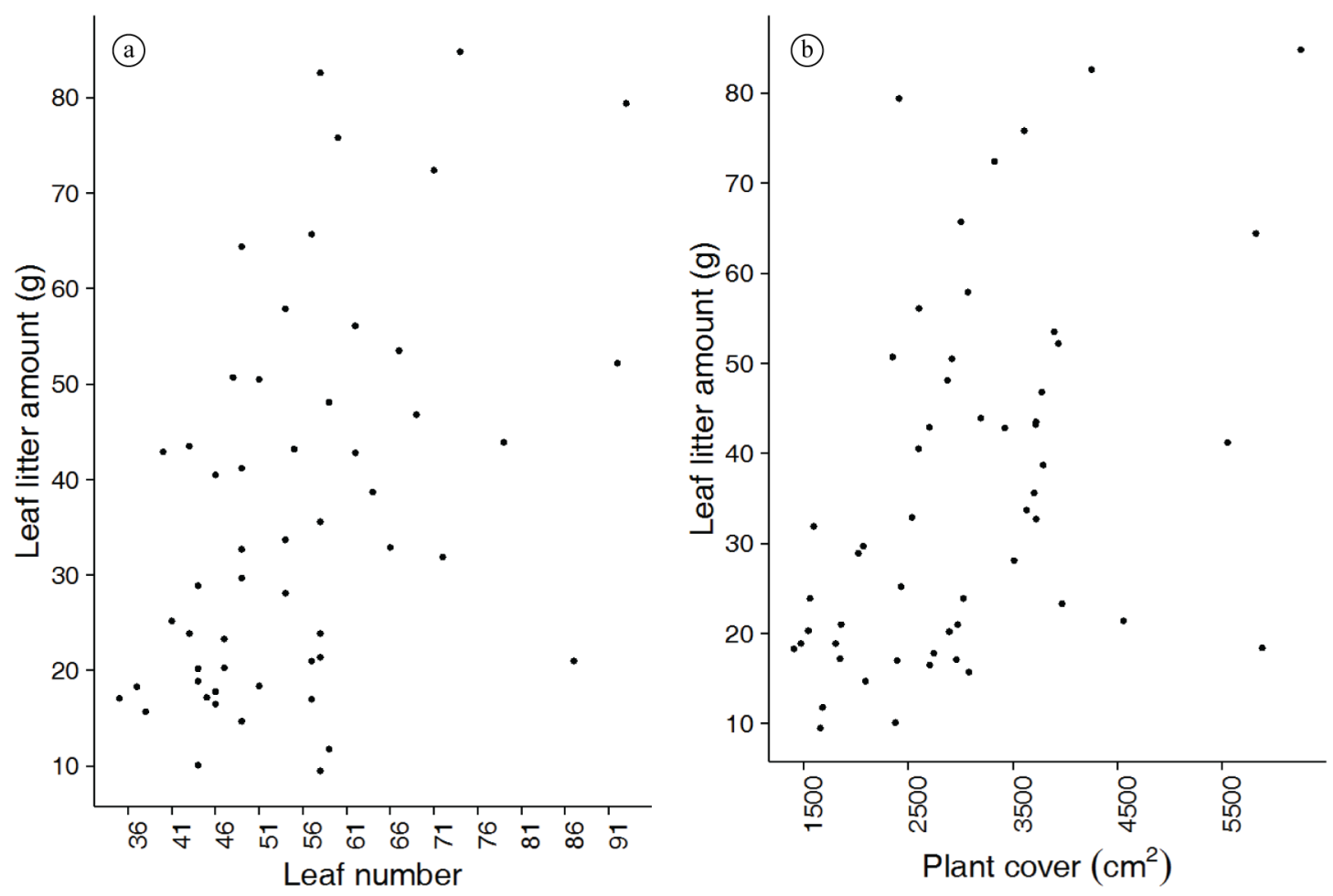

Figure 1. Relation between bromeliad variables and leaf litter amount. (a). Leaf number. (b). Plant cover.

the data and the group of candidate models, plant cover is 0.2 times more plausible or probable than leaf number, and 0.36 times more probable than sheath length.

\section{Discussion}

Bromeliads are a relevant component of Neotropical forests where bromeliads have high abundance and richness (Lugo and Scatena, 1992). Our study sought to determinate the relation between litter intercepted by bromeliads and bromeliad size and complexity. We found a relationship between leaf litter amount on Tillandsia turneri, which is the most abundant bromeliad in the study area, and bromeliad plant structure, measured through bromeliad leaf number, sheath length, and plant cover.

Plant leaf number is a measure of habitat complexity, which is the spatial subdivision of a habitat at a scale smaller than the mobility of individuals (Srivastava, 2006). The rosette dispositions of bromeliad leaves allow the creation of small tanks, where the plant can reserve rain water and leaf litter from the canopy (Benzing, 1980). The complexity of this micro-ecosystem increases with higher bromeliad leaf numbers, leading to more litter retention on the bromeliad and, as a result, increasing the diversity of associated organisms.

Plant cover and sheath length are related to bromeliad size. Plant cover refers to estimates of the bromeliad's area for interception of water and canopy leaf litter; accordingly, plants with high plant cover values will have greater amounts of resources, thereby increasing the probability of associated organisms (Lawton and Schroder, 1977; Araújo et al., 2007). Studies of Guzmania spp. and Vriesia spp. have reported a linear relationship between leaf litter and plant cover (Richardson, 1999). The sheath, which is the basal portion of the leaf, is the space in which the bromeliad retains water and litter received from the canopy; hence, an increase in sheath length leads to a greater tank size and a higher probability of retaining more leaf litter.

Bromeliads species vary in their traits associated with plant structure, such as diameter, leaf number, tank number, leaf length, and leaf width (e.g. GonçalvesSouza et al., 2011; Marino et al., 2013); moreover, these variations occur within-species (Zytynska et al., 2012). According to our results, bromeliads with differences in plant cover, leaf number, and sheath length would differ in the amount of intercepted litter, leading to a shift in bromeliad contribution to nutrient cycling and the spatial heterogeneity of litter distribution.

Overall, the variables that we found relevant to determine leaf litter amount in Tillandsia turneri are related to the area available for receiving leaf litter from the canopy, as well as to the number and size of tanks available for retaining the leaf litter. These models can be used to predict the energy input into the aquatic micro-ecosystem, which is known to affect community richness, complexity, and ecosystem functioning. 


\section{References}

ALVAREZ-SANCHEZ, J. and GUEVARA, S., 1999. Litter interception on Astrocaryum mexicanum Liebm. (Palmae) in a tropical rain forest. Biotropica, vol. 31, pp. 89-92. http://dx.doi. org/10.1111/j.1744-7429.1999.tb00119.x.

ANDERSON, D.R., 2008. Model based inference in the life sciences: a primer on evidence. New York: Springer Science. 208 p.

ANDERSON, N.H. and SEDELL, J.R., 1979. Detritus processing by macroinvertebrates in stream ecosystems. Annual Review of Entomology, vol. 24, no. 1, pp. 351-377. http://dx.doi.org/10.1146/ annurev.en.24.010179.002031.

ARAÚJO, V.A., MELO, S.K., ARAÚJO, A.P., GOMES, M.L. and CARNEIRO, M.A., 2007. Relationship between invertebrate fauna and bromeliad size. Brazilian Journal of Biology $=$ Revista Brasileira de Biologia, vol. 67, no. 4, pp. 611-617. http://dx.doi. org/10.1590/S1519-69842007000400004. PMid:18278311.

ARMBRUSTER, P., HUTCHINSON, R.A. and COTGREAVE, P., 2002. Factors influencing community structure in a South American tank bromeliad fauna. Oikos, vol. 96, no. 2, pp. 225-234. http://dx.doi.org/10.1034/j.1600-0706.2002.960204.x.

BENZING, D.H. and RENFROW, A., 1974. The nutritional status of Encyclia tampensis and Tillandsia circinata, on Taxodium ascendens, and the availability of nutrients to epiphytes on this host in south Florida. Bulletin of the Torrey Botanical Club, vol. 101, no. 4, pp. 191-197. http://dx.doi.org/10.2307/2484643.

BENZING, D.H., 1980. The biology of bromeliads. California: Mad River Press, Eureka. 305 p.

BENZING, D.H., 1990. Vascular epiphytes. Cambridge: Cambridge University Press. 354 p.

BENZING, D.H., 2000. Bromeliaceae: profile of an adaptive radiation. Cambridge: Cambridge University Press. 710 p.

CHEVAN, A. and SUTHERLAND, M., 1991. Hierarchical partitioning. The American Statistician, vol. 45, no. 2, pp. 90-96. http://dx.doi.org/10.2307/2684366.

CRUZ-RUIZ, G.I., MONDRAGÓN, D. and SANTOS-MORENO, A., 2012. The presence of Abronia oaxacae (Squamata: Anguidae) in tank bromeliads in temperate forests of Oaxaca, México. Brazilian Journal of Biology $=$ Revista Brasileira de Biologia, vol. 72, no. 2, pp. 337-341. http://dx.doi.org/10.1590/S151969842012000200015. PMid:22735142.

ESTEVEZ VARON, J.V. and VIÑA, A., 1999. Producción y Descomposición de hojarasca en Tres Estadios sucesionales de un Bosque de montaña en el Municipio de Chocontá, Cundinamarca, Colombia. Bogotá: Fondo FEN. 65 p. Informe.

FRANK, J.H., 1983. Bromeliad phytotelmata and their biota, especially mosquitos. In: H. Frank and P.L. Lounibos, eds. Phytotelmata: terrestrial plants as hosts of aquatic insects communities. New Jersey: Plexus, Inc., pp. 101-128.

GONÇALVES-SOUZA, T., ALMEIDA-NETO, M. and ROMERO, G.Q., 2011. Bromeliad architectural complexity and vertical distribution predict spider abundance and richness. Austral Ecology, vol. 36, no. 4, pp. 476-484. http://dx.doi.org/10.1111/j.14429993.2010.02177.x

HATTENSCHWILER, S., TIUNOV, A.V. and SCHEU, S., 2005. Biodiversity and litter decomposition in terrestrial ecosystems. Annual Review of Ecology Evolution and Systematics, vol.
36, no. 1, pp. 191-218. http://dx.doi.org/10.1146/annurev. ecolsys.36.112904.151932.

HOLDRIDGE, L.R., 1967. Life zone ecology. San José, Costa Rica: Tropical Science Center. 216 p.

ISAZA, C., BETANCUR, J. and ESTÉVEZ VARÓN, J.V., 2004. Vertical distribution of bromeliads in a montane forest in the Eastern cordillera of the colombian Andes. Selbyana, vol. 25, no. 1, pp. 126-137.

LASSO, E. and ACKERMAN, J.D., 2013. Nutrient limitation restricts growth and reproductive output in a tropical montane cloud forest bromeliad: findings from a long-term forest fertilization experiment. Oecologia, vol. 171, no. 1, pp. 165-174. http://dx.doi. org/10.1007/s00442-012-2403-z. PMid:22767363.

LAWTON, J.H. and SCHRÖDER, D., 1977. Effects of plant type, size of geographical range and taxonomic isolation on number of insect species with British plants. Nature, vol. 265, no. 5590, pp. 137-140. http://dx.doi.org/10.1038/265137a0.

LODGE, D.J., 1996. Microorganisms. In: D.P. REAGAN and R.B. WAIDE, eds. The food web of a tropical rain forest. Chicago: University of Chicago Press, pp. 53-108.

LUGO, A.E. and SCATENA, F.N., 1992. Epiphytes and climate change research in the caribbean: a proposal. Selbyana, vol. 13, pp. 123-130.

MALONEY, D.C. and LAMBERTI, G.A., 1995. Rapid decomposition of summer input leaves in a northern Michigan stream. American Midland Naturalist, vol. 133, no. 1, pp. 184-195. http://dx.doi. org/10.2307/2426360.

MARINO, N.A.C., SRIVASTAVA, D.S. and FARJALLA, V.F., 2013. Aquatic macroinvertebrate community composition in tankbromeliads is determined by bromeliad species and its constrained characteristics. Insect Conservation and Diversity, vol. 6, no. 3, pp. 372-380. http://dx.doi.org/10.1111/j.1752-4598.2012.00224.x.

MONTERO, G., FERUGLIO, C. and BARBERIS, I.M., 2010. The phytotelmata and foliage macrofauna assemblages of a bromeliad species in different habitats and seasons. Insect Conservation and Diversity, vol. 3, no. 2, pp. 92-102. http:// dx.doi.org/10.1111/j.1752-4598.2009.00077.x.

NGAI, J.T. and SRIVASTAVA, D.S., 2006. Predators accelerate nutrient cycling in a bromeliad ecosystem. Science, vol. 314, no. 5801, pp. 963 . http://dx.doi.org/10.1126/science.1132598. PMid:17095695.

OSPINA, M.F., ESTEVEZ VARON, J.V., BETANCUR, J. and REALPE, E., 2004. Macroinvertebrados acuáticos asociados a la bromelia Tillandsia turneri en un bosque altoandino. Revista Acta Zoológica Mexicana, vol. 20, no. 1, pp. 153-166.

OSPINA, M.F., ESTEVEZ VARON, J.V., REALPE, E. and GAST, F., 2008. Diversidad de invertebrados acuáticos asociados a Bromeliaceae en un bosque de montaña. Revista Colombiana de Entomologia, vol. 34, no. 2, pp. 224-229.

R DEVELOPMENT CORE TEAM, 2013. $R$ : a language and environment for statistical computing. Vienna: R Foundation Statistical Computing

RICHARDSON, B., 1999. The bromeliad microcosm and the assessment of faunal diversity in a Neotropical Forest. Biotropica, vol. 31, no. 2, pp. 321-336. http://dx.doi.org/10.1111/j.1744-7429.1999. tb00144.x.

RICHARDSON, B., ROGERS, C. and RICHARDSON, M.J., 2000. Nutrients, diversity, and community structure of two phytotelm systems in a lower montane forest, Puerto Rico. 
Ecological Entomology, vol. 25, no. 3, pp. 348-356. http://dx.doi. org/10.1046/j.1365-2311.2000.00255.x.

SAHA, N., ADITYA, G. and SAHA, G.K., 2009. Habitat complexity reduces prey vulnerability: an experimental analysis using aquatic insect predators and immature dipteran prey. Journal of Asia-Pacific Entomology, vol. 12, no. 4, pp. 233-239. http:// dx.doi.org/10.1016/j.aspen.2009.06.005.

SRIVASTAVA, D., 2006. Habitat structure, trophic structure and ecosystem function: interactive effects in a bromeliad-insect community. Oecologia, vol. 149, no. 3, pp. 493-504. http://dx.doi. org/10.1007/s00442-006-0467-3. PMid:16896779.

SWIFT, M.J., HEAL, O.W. and ANDERSON, J.M., 1979. Decomposition in terrestrial ecosystems. Oxford: Blackwell Scientific. 372 p. Studies in Ecology, no. 5.
YANOVIAK, S.P., 1999. Effects of leaf litter species on macroinvertebrate community properties and mosquito yield in Neotropical tree hole microcosms. Oecologia, vol. 120, no. 1, pp. 147-155. http://dx.doi.org/10.1007/s004420050843.

ZOTZ, G. and VERA, T., 1999. How much water is in the tank? Model calculations for two epiphytic bromeliads. Annals of Botany, vol. 83, no. 2, pp. 183-192. http://dx.doi.org/10.1006/ anbo.1998.0809.

ZYTYNSKA, S.E., KHUDR, M.S., HARRIS, E. and PREZIOSI, R.F., 2012. Genetic effects of tank-forming bromeliads on the associated invertebrate community in a tropical forest ecosystem. Oecologia, vol. 170, no. 2, pp. 467-475. http://dx.doi.org/10.1007/ s00442-012-2310-3. PMid:22466862. 